\title{
Effect of Cutting Size on the Rooting of Thuja occidentalis 'Columna'
}

\author{
Anna-Mária SZÁSZ-LEN ${ }^{1 *}$, Liviu HOLONEC ${ }^{1)}$, Alina TRUȚA ${ }^{1)}$, Florin Alexandru REBREAN ${ }^{1)}$ \\ ${ }^{1)}$ Department of Forestry, University of Agricultural Sciences and Veterinary Medicine Cluj-Napoca, \\ Mănăștur street 3-5, 400372, Cluj-Napoca; \\ *) corresponding author, e-mail: hannasas0@gmail.com
}

BulletinUASVM Horticulture 72(1) / 2015

Print ISSN 1843-5254, Electronic ISSN 1843-5394

DOI:10.15835/buasvmcn-hort:10999

\begin{abstract}
Rooting process plays a key role in the vegetative propagation of the ornamental coniferous, and insufficient rooting causes substantial losses in the propagation industry. Cuttings of Thuja occidentalis ,Columna' planted in the greenhouse of Mihai Viteazul Nursery Garden from Turda were examined after selecting the cuttings in three size categories. Experimental design included three cutting lengths $(10,15$ and $20 \mathrm{~cm})$ and each were growing without rooting hormones. Cutting length is an important factor that affecting rooting. The exact length of the cuttings is dependent upon the selected species used in vegetative propagation. The presence of leaves on a cutting is important also for root formation and development. In our experiment we planted stem cuttings with leaves and length between 10 and $20 \mathrm{~cm}$. The first measurement it was take in the $12^{\text {th }}$ week of rooting process, the second was take in the $18^{\text {th }}$ week of the rooting process. Significant differences were shown among cuttings from the three category in root number per cutting but not in root length per cutting after 18 weeks. Medium length cuttings (15 $\mathrm{cm}$ ) had significant influence on root number per cuttings. For optimal rooting, we recommend using $15 \mathrm{~cm}$ long cuttings.
\end{abstract}

Keywords: cutting length, root number/cutting, root lenght/cutting, Thuja occidetalis 'Columna'

\section{INTRODUCTION}

Europeans have grown Thuja occidentalis with decorative purposes. Thuja occidentalis ,Columna', has a strictly columnar and narrow crown, ten years old specimens can grows up to 6,5-7,5 $\mathrm{m}$ tall and $1-1,3 \mathrm{~m}$ in width. It has twisted stalks, arranged in horizontal planes with intense green color. Stalks and leaves forms a fine foliage structure which clearly separates from 'Buchanani', 'Holmstrup', 'Rosenthalii' varieties. The ,Columna' variety is taller and wider than the ,Pyramidalis Compacta' variety, but is more similar to ,Fastigiata' variety with the difference that it is narrower and the cones are less prominent (Schmidt and Tóth, 2006). This variety is popular in Romania because is tolerate a wide range of soil and climatic conditions. Thanks to the decorative attributes of Thuja occidentalis ,Columna' exist a great interest in the propagation of them. To establish an efficient vegetative propagation process it have to study factors as cutting length that have an influence on rooting process (Muñoz-Gutiérrez et al., 2009; Ullah et al., 2012).

\section{AIMS AND OBJECTIVES}

This paper aims to follow rooting process influenced by the size of Thuja occidentalis 'Columna' cuttings.

\section{MATERIALS AND METHODS}

Experiments were placed in "Mihai Viteazul" Nursery Garden from Turda, in spring 2013. In the experience were used simple lignified stem cuttings. The fresh Thuja occidenatalis 'Columna' cuttings from the nursery' field were selected in three size categories: small $(10 \mathrm{~cm})$, medium $(15$ $\mathrm{cm})$ and large $(20 \mathrm{~cm})$. We planted 120 cuttings in each size category. The harvested cuttings were piped without storing to increase the rooting probability. 
Tab.1. Average root number per cutting in the size categories of Thuja occidentalis ,Columna' cuttings

\begin{tabular}{|c|c|c|c|c|c|c|}
\hline \multirow{2}{*}{ Cuttings size } & \multicolumn{2}{|c|}{ Average no. of roots in the $12^{\text {th }}$ week (piece) } & \multicolumn{3}{c|}{ Average no. of roots in the $18^{\text {th }}$ week (piece) } \\
\cline { 2 - 7 } & Relative & Absolute (\%) & Sign. of differences & Relative & Absolute (\%) & Sign. of differences \\
\hline Small & 4.2 & 96.6 & -0.1 & 5.2 & 89.7 & -0.6 \\
\hline Medium & 4.4 & 100.8 & 0.0 & 6.8 & 11.2 & $1.0^{*}$ \\
\hline Large & 4.5 & 102.6 & 0.1 & 5.4 & 93.1 & -0.4 \\
\hline Media(Mt) & 4.3 & 100.0 & Mt & 5.8 & 100.0 & Mt \\
\hline
\end{tabular}

DL (5\%) 1,6; DL (1\%) 2,3; DL (0,1\%) 3,5; DL (5\%) 1,1; DL (1\%) 1,6; DL (0,1\%) 2,3;

Tab. 2. Average root length per cutting in the size categories of Thuja occidentalis ,Columna' cuttings

\begin{tabular}{|c|c|c|c|c|c|c|}
\hline \multirow{3}{*}{ Cuttings size } & \multicolumn{2}{|c|}{ Average root length in the $12^{\text {th }}$ week $(\mathrm{cm})$} & \multicolumn{3}{c|}{ Average root length in the $18^{\text {th }}$ week $(\mathrm{cm})$} \\
\cline { 2 - 7 } & Relative & $\begin{array}{c}\text { Absolute } \\
\text { (\%) }\end{array}$ & Sign. of differences & Relative & Absolute (\%) & Sign. of differences \\
\hline Small & 1.6 & 89.6 & -0.2 & 4.2 & 96.6 & -0.1 \\
\hline Medium & 2.0 & 109.7 & 0.2 & 4.4 & 100.8 & 0.0 \\
\hline Large & 1.8 & 100.7 & 0.0 & 4.5 & 102.6 & 0.1 \\
\hline Media(Mt) & 1.8 & 100.0 & Mt & 4.3 & 100.0 & Mt \\
\hline
\end{tabular}

DL (5\%) 0.4; DL (1\%) 0.5; DL (0.1\%) 0.8; DL (5\%) 1.6; DL (1\%) 2.3; DL (0.1\%) 3.5;

\section{Results and Discussion}

It was followed the rooting process of the cuttings from the three different size categories. The average root number per cutting significantly increased in medium sized cuttings in the $18^{\text {th }}$ week of the rooting process (Tab. 1). The cuppressaceae Thuja occidenatalis 'Columna' $15 \mathrm{~cm}$ long medium size cuttings presented average 6,8 roots per cutting in the $18^{\text {th }}$ week. Iliev et al. (2010) found similar results in the case of cuppressaceae Chamaecyparis lawsoniana ,Columnaris' non IBA treated 8-12 cm long cuttings with 6,1 $\pm 0,6$ average root number after 17 week. MuñozGutiérrez et al. (2009) propagated $12-15 \mathrm{~cm}$ sized Taxus globosa cuttings which were treated with rooting hormones, and the average number of roots formed was between 4,2-5,3 after 5 months rooting. Based on Ullah et al. (2012) study the 15 $\mathrm{cm}$ height olive (Olea europea L.) cuttings resulted the maximum average number of roots $(13,43)$ in the case of all 5 cultivars.

The average root length had no significant differences among different heights of Thuja occidentalis 'Columna' cuttings in the $12^{\text {th }}$ week neither in the $18^{\text {th }}$ week (Tab. 2). 10, 15 and $20 \mathrm{~cm}$ long cuttings had similar average root lenght, 4,2$4,5 \mathrm{~cm}$ in the $18^{\text {th }}$ week. Iliev et al. (2010) found in the case of non IBA treated $8-12 \mathrm{~cm}$ Chamaecyparis lawsoniana ,Columnaris' cuttings $3,72 \pm 0,18 \mathrm{~cm}$ average root length after 17 week. Desrochers and Thomas (2003) found that $10 \mathrm{~cm}$ height Populus spp. cuttings had 29\% greater rooting success than $5 \mathrm{~cm}$ height cuttings had. For optimal rooting it is recommended to use $10 \mathrm{~cm}$ height Populus spp. cuttings without any additional hormone substance. Based on Ullah et al. (2012) study for the five olive cultivars the maximum average root length was $11,24 \mathrm{~cm}$ for the $20 \mathrm{~cm}$ length cuttings, while $15 \mathrm{~cm}$ height olive (Olea europea L.) cuttings resulted $8,23 \mathrm{~cm}$ average root lenght, $35 \mathrm{~cm}$ height olive cuttings resulted the minimum average root length $5,2 \mathrm{~cm}$.

\section{Conclusion}

Seedlings of Thuja occidentalis 'Columna' are often used in urban landscape. Thuja occidentalis 'Columna' is a particularly valuable ornamental conifer used as hedges and alignments. Production by cuttings is the easiest and a commonly used method. Medium-sized cuttings had a strong influence on the rooting of Thuja occidenatalis 'Columna' cuttings. For optimal rooting. we recommend using $15 \mathrm{~cm}$ cuttings.

\section{REFERENCES}

1. Iliev I, Iliev N, Dancheva D, Corneanu M, Tsaktsira M, Gajdosova A, Mladenova S (2010). Factors affecting the rooting of cuttings from cultivars of Chamaecyparis lawsoniana (A. Murr.) Parl. Analele Universității din Craiova. Seria Agricultură-Montanologie-Cadastru Vol. $\mathrm{XL} / 2$.

2. Schmidt G,Tóth I (2006). Kertészeti dendrológia [Horticultural Dendrology] Budapest. Mezőgazda Press. 414.

3. Desrochers A, Thomas BR (2003). A comparison of preplanting treatments on hardwood cuttings of four hybrid poplar clones. New Forests. 26:17-32.

4. Muñoz-Gutiérrez L, Vargas-Hernández JJ, López-Upton J, Soto-Hernández M (2009). Effect of cutting age and substrate temperature on rooting of Taxus globosa. New forests 38(2):187-196.

5. Ullah E,Awan AA, Abbas SJ, Ullah F, Masroor S, Khan 0 (2012). Growth response of various olive cultivars to different cutting lengths. Pak. J. Bot. 44(2): 683-686. 